\title{
COMMENT
}

\section{CHARITABLE SUBSCRIPTIONS IN ILLINOIS}

\author{
Lewis C. Murtaugh*
}

$\mathrm{P}$ ROMISES which lack a consideration have been so frequently enforced on the basis of the doctrine of promissory estoppel that it is be recognized. The question of the extent to which the doctrine will be be recognized. ${ }^{x}$ The question of the extent to which the doctrine will be allowed to supersede the requirement of consideration for the enforcement of promises is one that it may confidently be predicted will be worked out only in the greatest confusion in which the elements of consideration, estoppel and promissory estoppel may be expected to be confused and misnamed. ${ }^{2}$

In the van in creating such legal bedlam are the cases enforcing the payment of promised sums to charities. ${ }^{3}$ To those familiar either with history or with current events, it is a commonplace that the policy of nations towards charities, especially religious institutions, varies. In this country charities seem to be in universal favor and the courts have gone to great extent to make this clear. ${ }^{4}$ Their extent and growth is a matter of common knowledge.

* Member of the Tllinois bar.

I See I Williston, Contracts $\$$ I39 (2d ed. I936); also Cardozo, J., in Allegheny College v. National Chautauqua County Bank, 246 N.Y. 369, I59 N.E. I73 (x927).

2 Estoppel may arise if there is justifiable detrimental reliance upon a representation of fact; promissory estoppel when there is justifiable detrimental reliance upon the performance of a promise. If the act done by the promisee is bargained for as a return for the promise, it may be consideration. The mere performance of a condition, however detrimental, attached to a gratuitous promise is not consideration. See I Williston, Contracts $\$$ I39 (2d ed. I936). Interesting cases of real estoppel based úpon a promise are Golden v. Cervenka, $278 \mathrm{Ml}$. 409, II6 N.E. 273 (I9I7), and Niblack v. Farley, 286 Ill. 536, 540, I22 N.E. I60 (I9I9), in which notes given to a bank without consideration to create the appearance of assets were enforced by the receiver on the closing of the bank. For a comment on an "injurious reliance" theory for enforcing all promises, see Cohen, The Basis of Contract, 43 Harv. L. Rev. 553, 578 (I933).

3 For an analysis and citation of authority on charitable subscriptions generally, see I Williston, Contracts $\S$ II6 (2d ed. 1936); T. C. Billig, The Problem of Consideration in Charitable Subscriptions, I2 Corn. L. Q. 467 (I927), reprinted in American Law School Association, Selected Readings on the Law of Contracts 542 (I93I); and extended notes in 38 A.I.R. 868 (I925) and 95 A.L.R. I305 (I935).

4 Continental Illinois National Bank and Trust Co. v. Harris, 359 Ill. 86, I94 N.E. 250 (I935), and cases cited therein. 
One of the commonest means by which their continuance and growth is effectuated is by the subscription drive. ${ }^{5}$ This results in the charity having large amounts of promises represented by notes or subscription agreements of various sorts. On the performance of these promises, charities sometimes depend for their very existence, sometimes for their growth. ${ }^{6}$ The courts have generally been very willing to see that these expectations are not frustrated by a change of heart on the part of the promisor or by his untimely death. ${ }^{7}$ Although such promises have been enforced for a great variety of reasons, the favored device has been by the application of the doctrine of promissory estoppel. Even when other elements of the alleged contract were enlarged upon, the courts have usually made the promissory estoppel element part and parcel of their decision. Thus, because of such frequent enforcement, it has been suggested ${ }^{8}$ that the promissory estoppel section of the Restatement of Contracts ${ }^{9}$ should have been supplemented by a rule of law that a written subscription to a charity should not be invalid or unenforceable for want of consideration. However, such a rule of law can almost be reached by a sympathetic definition of the reliance necessary for promissory estoppel. For in many states, reliance seems to be that measure of reliance upon the promise to make a gift to charity which actually was taken by the charity before the court. Such a sophisticated conclusion may be supported by decisions finding the necessary reliance in the obtaining of subscriptions, in the subscriptions of others or in the mere continued existence of the charity, as well as the more obvious building of a church or school..$^{\mathbf{0}}$ In a recent

5 Promises obtained in a subscription drive differ from isolated promises in that the latter lack a possible consideration arising from other subscriptions, or from the labor of obtaining other subscriptions. Frequently, too, a subscription is for a more definite purpose the accomplishment of which is easily denominated reliance. For these reasons and because they are by far the commonest sort of promises which have reached the courts, only subscription promises are considered herein, unless specially designated otherwise.

${ }^{6}$ The cases seem not to have discussed the worth of continuance of particular charities or to question the value of expansion of their activities.

7 See, generally, authorities cited in note 3 supra. For Illinois cases see note I6 infra. It seems always to have been presumed that the charity has reasonably relied on the promised sum unless the promise was withdrawn before reliance. See note 35 infra.

${ }^{8}$ T. C. Billig, op. cit. supra note 3 , at 480 .

9 Rest., Contracts $\$ 90$ (I932): "A promise which the promisor should reasonably expect to induce action or forbearance of a definite and substantial character on the part of the promisee and which does induce such action or forbearance is binding if injustice can be avoided only by enforcement of the promise."

ro See note 3 supra for authorities generally. Note that the reliance referred to is present in any subscription case. 
Illinois Appellate Court decision, ${ }^{\text {II }}$ the relatively ascetic conceptions of the earlier Illinois cases on promissory estoppel were broadened to include almost all of these "reliances."

The Mlinois cases without recognizing the term have clearly relied upon a promissory estoppel principle in sustaining charitable ${ }^{\mathrm{x} 3}$ and non-charitable $^{x_{4}}$ subscriptions, ${ }^{{ }_{15}}$ even though oftentimes there was a definitely recognizable consideration for the subscription. ${ }^{16}$ Sometimes there were clearly mutual promises between subscribers for the benefit of the charity. ${ }^{17}$ Promises of subscribers to each other might be consideration without the necessity of any mention of promissory estoppel, ${ }^{18}$ but usually the court has brought in the point of reliance. ${ }^{\text {I9 }}$

The content of the promissory estoppel doctrine was not subjected to much analysis until the courts were confronted with sets of facts which in

${ }^{11}$ In re Estate of Wheeler, 284 Ill. App. r32, I N.E. (2d) 425 (1936). No attempt to secure a further review was made.

r2 The labor of obtaining subscriptions, however, was not relied upon.

$x_{3}$ Robertson v. March, 3 Scam. (4 Ill.) I98 (I84I); Pryor v. Cain, 25 Ill. 263 (186I); Griswold v. Trustees of Peoria University, 26 Ill. 4I (I86r); Johnston v. Ewing Female University, 35 Ill. 518 ( 1864 ); Trustees v. Garvey, 53 Ill. 40 ( 1870 ); Snell v. Trustees, 58 Ill. 290 (I87r); Whitsitt v. Trustees, r ro Ill. r.25 (r884); Hudson v. Green Hill Seminary, Ir3 Ill. 6r8 (1885); Beatty v. Western College, I77 III. 280, 52 N.E. 432 (I898).

I4 Cross v. Pinckneyville Steam Co., I7 Tll. 54 (1855); Thompson v. Board of Supervisors, 40 Ill. 379 (I866); McClure v. Wilson, 43 Ill. 356 (I867); Miller v. Ballard, 46 Ill. 377 (I868); Hall v. Virginia, gr Ill. 535 (r879); Richelieu Hotel Co. v. Military Encampment Co., I4० Ill. 248, 29 N.E. I044 (I892); Grubbs v. Kelly, I49 Ill. App. 550 (I909). Regarding preincorporation promises to subscribe generally, see I Williston, Contracts $\S$ Ir8 (2d ed. I936).

is As in the Restatement, note ro supra, no distinction was made between charitable and non-charitable subscriptions.

${ }^{16}$ Thompson v. Board of Supervisors, 40 Ill. 379 (I866); Hall v. Virginia, 9r Ill. 535 (I879); (relocation of a county seat); McClure v. Wilson, 43 Ill. 356 (r867) (escaping Civil War draft); Richelieu Hotel Co. v. Military Encampment Co., r40 Ill. 248, 29 N.E. I044 (I892), and Miller v. Ballard, $46 \mathrm{Ill} .377$ (I868) (securing a convention); Grubbs v. Kelly, I49 Ill. App. 550 (I909) (securing a new industry and railroad for the town).

${ }^{17}$ Whitsitt v. Trustees, xIo Tll. I25 (1884). In some of the cases, especially where noncharitable subscriptions were involved, the agreements might have been so construed.

${ }^{18}$ Tonica \& Petersburg Railroad Co. v. McNeely, 2I IIl. 7x (I859); see Chicago Bank of Commerce v. Kraft, 269 Ill. App. 295 (r933).

19 Thus, in Whitsitt v. Trustees, IroIll. I25 (1884), the court said at page I3I, "It has often been held, in the case of mutual subscriptions for a common object, and there has been expenditure of money in the accomplishment of the object, that a subscription is binding as a valid contract, expenditures having been made on account thereof." 
the courts' eyes did not merit recovery. ${ }^{20}$ In Pratt v. Trustees, ${ }^{21}$ the promisor died before the purchase of a bell, which was to be paid for in part by the sum he had promised. The court held that since no action had been taken, death revoked the offer and there was no liability. ${ }^{22}$ In Beach $v$. First M.E. Church, ${ }^{23}$ the same result was reached when insanity of the promisor intervened before the construction of a church was begun. Again, in an appellate court case, ${ }^{24}$ a subscriber withdrew before the commencement of the work of remodeling, the expenses of which he had promised to defray in part, and the court refused to hold him liable. The court denied that the labors of the pastor in getting the necessary subscriptions were sufficient reliance. The court considered that an earlier case ${ }^{25}$ to the contrary could not stand in view of the later cases just discussed. Since this element of labor is always present and this consideration has not been relied upon successfully since that time, the conclusion seems justified. ${ }^{26}$

The case of Beatty v. Western College ${ }^{27}$ reinforced the principle of the Beach and Pratt cases and in addition clarified the legal situation. The court disregarded an expressed consideration in the note on the ground that the proof tended to show that the note was a gift or donation ${ }^{28}$ and that such promises were enforced only "if money has been expended or liabilities have been incurred which by legal necessity must cause loss or injury to the person so expending money or incurring liability, if the note

20 Illinois cases denying recovery to charities are Pratt v. Trustees, 93 Ill. 475 (1879); Beach v. First Methodist Church, 96 Ill. 177 (1880); Augustine v. Trustees of Methodist Episcopal Society, 79 Ill. App. 452 (I898); Cutwright v. Preachers Aid Society, 27I Ill. App. I68 (I933). To these might be added Kelly v. Dyer, 359 IIl. 46, I94 N.E. 255 (I935), although an inspection of the briefs indicates that the argument was not based upon the fact that the promisee was a charity.

${ }^{2 x} 93$ Ill. 475 (I879).

${ }^{2} I d$. at 478 : "Where notes are given by way of voluntary subscription, to raise a fund or promote an object, they are open to the defence of a want of consideration, unless money has been expended, or liabilities incurred which, by a legal necessity, must cause loss or injury to the person so expending money, or incurring liability, if the notes are not paid. . . . It is the expending of money, etc., or incurring of legal liability, on the faith of the promise, which gives the right of action, and without this there is no right of action."

${ }^{23} 96$ Ill. 177 (1880).

${ }_{24}$ Augustine v. Trustees of Methodist Episcopal Society, 79 Ill. App. $45^{2}$ (I898).

${ }_{25}$ Kentucky Baptist Education Society v. Carter, 72 Ill. 247 ( 1874 ).

${ }^{26}$ The court, in Cutwright v. Preachers Aid Society, 27I Ill. App. 168 (I933), denied that either the labor of obtaining subscriptions or the subscriptions themselves were consideration.

${ }^{27}$ I 77 Ill. 280,52 N.E. 532 ( 1898 ). Recovery was allowed because a building had been built in the expectation that the sum promised would be available to pay for it.

${ }^{28}$ See I Williston, Contracts Ir6 (2d ed. I936). 
is not paid." 29 In such cases, said the court, "The gift will be upheld upon the ground of estoppel and not by reason of any valid consideration in the original undertaking." ${ }^{30}$ The opinion, by recognizing that reliance was not consideration, and that the enforcement of these promises was not based on contract principles did a great deal to clarify both the law of contracts and of charitable subscriptions in this state.

The seeming simplicity of promissory estoppel as limited by the opinions, however, is deceiving. If the charity procures a subscription on the basis of which it builds a building, the case for recovery is clear. Suppose the contract for the structure is signed but the building is not begun or has just begun when the promise of the sum was withdrawn. The liability incurred, the measure of damages of the church to the contractor would be considerably smaller than the full cost of the building. This would seem to be the measure of reliance also on a quantum meruit basis. Yet, the usual terminology that the promisor is estopped to plead lack of consideration would indicate that full recovery on the promise could be made. There are apparently no decisions allowing only a partial recovery. ${ }^{3 \mathbf{x}}$

Even though no actual liability was incurred or expenditure made which the performance of the promise was intended to cover, it would seem reasonable to allow recovery by the charity in at least one class of cases. Suppose A promises a charity the sum necessary to build a school and $B$ promises the charity the sums necessary to maintain it. It would be almost useless to enforce one without enforcing the other. The building of the school should clearly be enough reliance for both promises. The occurrence of considerable future liabilities and expenditures, even though not contracted for as yet, is so predictable that when the action giving rise to

29 Beatty v. Western College, I77 Ill. $280,293,52$ N.E. 432,435 (I898).

${ }^{30} \mathrm{Ibid}$. The court also adopted the following language from Simpson Centenary v. Tuttle, 7 I Iowa $596,599,33$ N.W. 74, 75 ( 1887 ): "Where a note, howeyer, is based on a promise to give for the support of the objects referred to (founding a school, church or other institution of similar character), it may still be open to this defense, (want of consideration), unless it shall appear that the donee has, prior to any revocation, entered into engagements or made expenditures based on such promise, so that he must suffer loss or injury if the note is not paid. This is based on the equitable principle that, after allowing the donee to incur obligations on the faith that the note would be paid, the donor should be estopped from pleading want of consideration."

3r It has been urged that, although the extent of reliance, rather than expectation, is an appropriate measure of damages for some contracts, charitable subscriptions should nevertheless be dealt with on the basis of expectations. Fuller and Perdue, The Reliance Element in Contract Damages, 46 Yale I.J. 52, 373, 405 (1936-37). There are, however, dicta that the amount of reliance measures the recovery. Pryor v. Cain, 25 Ill. 262, 265 (I86I); Miller v. Ballard, 46 Ill. 377, 380 (I868). Cf. Alexander Hamilton Institute v. Jones, 234 Ill App. 444 (r924). 
the liabilities has been undertaken in reliance upon a promise to defray them, there seems as much reason for enforcing this payment as for enforcing payment to defray the cost of the building itself. This result was reached in an early appellate court case. ${ }^{32}$ A promise to the endowment fund of a school not yet started but made to induce its foundation was enforced when the college was founded, teachers hired and other expenditures were made on the faith of the endowment fund of which the note formed a part. ${ }^{33}$

Suppose the promise to maintain the school was made after the school was built and in operation. The existence of the liabilities would not have been caused by any reliance upon the promise and without more it would seem clear that liability should be denied. The mere expectation of a new source of revenue would seem to be in the same class as the expectations in the unbuilt church ${ }^{34}$ and the unbought bell cases. ${ }^{35}$ Yet, this seems to have been denied by the appellate court in the recent case already mentioned..$^{36}$

In that case a promise was made to bequeath a sum to the endowment of a church, the income of which was to be used to meet its ordinary current expenses. No interest was paid by the promisor, who died twelve years later. The church was already built and prospering and it was to assure the continuity of its operation that the endowment fund drive had been undertaken. In Igr8 the income of the endowment fund contributed about two per cent of the current income. In I933 the income of the fund was almost thirty per cent of the total income. This was, of course, largely due to the drive which had brought large sums into the fund. However true to the prediction which caused the founding of the fund, the current contributions declined during the same period, although the membership increased. The court allowed the charity to recover even though there was no reference to any additional activities undertaken in reliance upon the fund as a means of support. ${ }^{37}$

32 Friedline v. Board of Trustees, 23 Ill. App. 494 (I887).

33 An important, though probably not crucial element was that interest had been paid on the note for a time.

34 Beach v. First M.E. Church, 96 III. I77 (I880). ${ }^{35}$ Pratt v. Trustees, 93 Ill. 475 (I879).

${ }^{36}$ In re Estate of Wheeler, 284 IIl. App. I32, I N.E. (2d) 425 (1936).

37 Id. at $\mathrm{I}_{45}$ (N.E. at $43 \mathrm{I}$ ):

"The statements of the receipts and disbursements show that the current income had so decreased by $x 933$ that the income from the endowment fund became a vital factor in carrying on the religious and charitable work of the church. The trustees say that, relying on the validity of the pledges to the endowment fund, they have carried on the work of the church in face of declining current income. ....

"We hold .... that there was a sufficient consideration by reason of the expenditure of money in carrying on the work of the church in reliance on the endowment fund. . . ." 
The court further indicated that in the continued operation of the charity, there is sufficient reliance for enforcing the payment of sums designed to maintain that operation in the future..$^{38}$ The logical justification may be that the charity, had it known of the future default, might have husbanded its resources and curtailed its operations so as to have sufficient funds for future expenses. The argument might also be made with regard to the promise to contribute to the purchase of a bell, that relying on the promise and not expecting to have to pay for the bell out of revenue, the usual rather than curtailed expenditures were made, therefore even though the bell was not bought or contracted for before the promise was withdrawn, liability should be enforced. ${ }^{39}$

The court in the Wheeler case has thus suggested that there should be an inference of reliance in favor of any going charity..$^{\circ}$ This seed, if the Wheeler case is an influence in the law, may be expected to develop, with proper handling, so that soon the inference of reliance might well become an almost conclusive presumption.

A word about the promissory estoppel doctrine in non-charity cases. If the necessary reliance is reduced to the minimum in charity cases, will cases involving promises for non-charitable purposes, subscription or otherwise, follow, and if so, will not the conception of consideration be outmoded? The Illinois courts have cited charitable and non-charitable subscription cases indiscriminately, and on the same authority the appellate court has sustained recovery on a non-subscription, non-charitable promise. ${ }^{4 \pi}$ It is hard to believe that the courts in later years have not been more concerned with the necessities of charities than with the justifiability of reliance or even with the existence of actual reliance. There seems no reason of policy for not scrutinizing these latter elements more carefully in non-charitable cases. The inference of reliance may eventually be the method for making a distinction between charitable and

${ }^{38}$ There is an intermediate situation: current operations might be expanded or otherwise change materially in reliance upon the promised sum, e.g., additional personnel contracts might be entered into or tuition lowered. It could be argued that these are just as much reliance as building. See Friedline v. Board of Trustees, 23 Ill. App. 494 (I887). Such situations might be readjusted more easily if the promised sum were not forthcoming. See note 35 supra. However, this would be a much stronger case for recovery than where current operations have continued without change.

${ }^{39}$ Cf. Pratt v. Trustees, 93 Mll. 475 (1879).

${ }^{40}$ Citing In re Estate of Griswold, $\mathrm{xI}_{3}$ Neb. 256, 202 N.W. 609 (I925); see also Irwin v. Lombard, 56 Ohio St. 9, 46 N.E. 63 (I897); First Presbyterian Church v. Dennis, 178 Iowa I352, I6r N.W. 183 (1917); of. Beatty v. Illinois, I77 Ill. 280, 52 N.E. 432 (x898).

${ }_{4 \mathrm{r}}$ Switzer v. Gertenbach, 122 Ill. App. 26 (1905). The leading case is Ricketts v. Scothor, 57 Neb. 51,77 N.W. 365 (1898). 
non-charitable subscription cases. The Wheeler case, however, is too slim a premise for concluding that the more restricted promissory estoppel doctrine, as worked out by many Illinois decisions, is no longer the limit of enforceability.

Prior to the Wheeler case, promises to subscribe had been enforced almost exclusively on a promissory estoppel as distinguished from a consideration basis. The statement in an early case ${ }^{42}$ that the labor of getting subscriptions was sufficient consideration for the promise to give has been considered overruled by the Prati and Beach cases. ${ }^{43}$ The Wheeler case, however, allegedly based its decision as much upon true consideration for the promise as upon reliance. The court found consideration for the decedent's promise in the promises and payments of others and in the "offer" of the church as expressed in the resolution which inaugurated the drive to receive any money given, to hold it in trust in perpetuity and to use the income for only certain of its purposes. ${ }^{44}$ Because almost any charitable subscription case could be so presented as to involve similar considerations, the court's position deserves close scrutiny.

In holding that the promises of the various pledgors, all of whom subscribed separately, were mutual and that the promises or payments of subsequent subscribers were consideration, the court seems to rely upon a fictitious interpretation of the facts. ${ }^{45}$ If any contract exists, it is between the charity and the subscriber. However the action of one charitably minded person may influence another, their separate promises are each direct to the charity and can hardly be termed mutual promises in consideration of each other. ${ }^{46}$ They are neither made to each other nor bar-

42 Kentucky Baptist Education Society v. Carter, 72 Ill. 247 (1874). The labor of getting subscriptions should be sufficient if bargained for as consideration. But this would rarely be the case. I Williston, Contracts $\S$ II2 (2d ed. I936).

${ }^{43}$ Augustine v. Trustees of Methodist Episcopal Society, 79 Ill. App. 452 (I898). Cutwright v. Preachers Aid Society, 27r Ill. App. 168 (1933).

44 The income could be used for local religious needs as distinguished from the church's missionary or charitable activities. The court considered the subscription reciting the considerations referred to in the text an acceptance of the offer. The court implied the promise to receive the gift. See note ${ }_{5} \mathrm{I}$ infra.

45 It is not clear that the court was not merely applying promissory estoppel on the theory that the subsequent payments by other subscribers were expenditures in reliance on the now defendant's promise. But since these donors neither expected nor were intended to be reimbursed by the Wheeler payment, the essence of the hardship that promissory estoppel was designed to remedy is absent and the doctrine is inapplicable. Note that Restatement requires reliance by the promisee for promissory estoppel. Rest., Contracts $\S 90$ (I932), quoted in note 9 supra.

${ }^{46}$ See Merchants Improvement Co. v. Chicago Exchange Bldg. Co., 210 Ill. 26, 33, 7x N.E. 22, 26 (1904). To subsequent pledgors the prior pledge would be past or executed and so no consideration, since their pledges are not enforceable for lack of consideration, they could 
gained for; two requisites for consideration in bilateral contracts. ${ }^{47}$ It is significant that, although numerous subscriptions have been present in almost every Illinois case, no court has ever relied on the point before. Besides, a recent appellate court decision has expressly denied the sufficiency of such consideration. ${ }^{48}$

Regarding as consideration the agreement to receive the funds, to act as trustee thereof, and to use the income only for certain of the promisees' purposes seems to conflict with the rule that gratuitous promises, ${ }^{49}$ even to create a trust, ${ }^{50}$ are unenforceable. For there should be little difficulty in either finding or implying a promise to receive the benefit if this may be called consideration for the promise to give..$^{5 x}$ The difficulty is not in finding or implying such a promise, it is in finding any reasonable ground for the assertion that there really was a bargain struck between the parties, ${ }^{52}$ and it is, further, in making such a promise qualify as consideration. ${ }^{53}$

hardly make the prior pledge enforceable. See I Williston, Contracts $\S$ roze. (2d ed. I936). Of course, as heretofore pointed, if subscribers promise each other for the benefit of a charity or an individual, an enforceable third party contract may arise.

${ }^{47}$ See I Williston, Contracts $\$ r 16$ (2d ed. I936).

${ }^{8} \mathrm{In}$ Cutwright v. Preachers Aid Society, 27I Ml. App. I68 (I933), the promise was expressed to be "in consideration of others subscribing." The court said at p. I7r, "There was no consideration of any kind for the execution of the instrument, except that expressed on the face of the instrument, which expresses no consideration." The Board of Tax Appeals, however, considers a charity's claim on such consideration to be valid in determining the net estates of decedents. Edna F. Hays, et. al., Extrs. (B.T.A. x936).

49 Richardson v. Richardson, I48 Ill. 563, 36 N.E. 608 (I893); Kelly v. Dyer, 359 Ill. 46, 194 N.E. 255 (I935) (note held by charity).

so Switzer v. Skiles, 8 Ill. 529, 535 (I846); McCartney v. Ridgway, I60 Ill. I29, I55, 43 N.E 826,835 (r8g6).

${ }^{5}$ Such an agreement might easily be implied from the acceptance of the signed subscription. See I Williston, Contracts $\S 90 a$ (2d ed. r936). The Wheeler case distinction of all previous Illinois cases whether or not liability was sustained because "in none of these cases appeared any promise by the donee or charity to do anything" (284 $\mathrm{Tl}$. App. 132, 140, I N.E. (2d) 425,428 ) seems irrelevant. In addition it is untrue since the promises of the church were solely as to funds received; thus, the court was forced to imply the promise to receive the funds, even in this case.

${ }^{5 z}$ If an actual bargain was based upon the consideration stated it should have been sustained. Rest., Contracts $\$ 84 a$ ( 1932 ). The courts generally will not consider the adequacy of a bargained-for consideration. Guyer v. Warren, I 75 Ill. 328, 335, 5 I N.E. 580 (I898); I Williston, Contracts $\S I_{55}(2 \mathrm{~d}$ ed. I936). Nevertheless, finding that a promise to accept a gift is bargained-for in exchange for a promise to give, seems both a stretch of the imagination and a reductio ad absurdum of the requirement of consideration in bilateral contracts. See Ballantine, Is the Doctrine of Consideration Senseless and Illogical? II Mich. L. Rev. 423 (I9I3).

53 Mutual promises are not the only requirement for a bilateral contract. If the performance promised is not enforceable, or if it is not sufficient consideration, neither is a promise of such performance sufficient. See I Williston, Contracts $\S$ Iozb (2d ed. 1936). 
There is room for doubt that the performance promised by a church in agreeing to use funds for certain of its purposes can qualify as detriment inasmuch as by law religious corporations are already in this state bound to hold gifts upon the terms given. ${ }^{54}$ This same duty is imposed on charities generally without a statute on ordinary trust principles. ${ }^{55}$ The court in the Whecler case felt nonetheless that there was detriment because of the promise to conserve the principal and to use the income for but some of its purposes, relying on section 84 (c) of the Restatement of Contracts which provides that if the act promised "differs in any way from what was previously due," it is sufficient. Reflection however, will show that the promised act did not differ in any way from the duty to use the gift for the purpose given ${ }^{56}$ and that the promise of the charity being merely to fulfill its obligation was therefore questionable consideration..$^{57}$

Another pertinent approach in testing the soundness of the opinion is to consider the rights that were created in the promisor. It is axiomatic that in a bilateral contract as the court considered this to be, both parties must be bound on the acceptance or neither is..$^{88}$ There must be enforceable rights created in each party by virtue of the contract. The fact of the existence of such rights may be tested by considering first the situation after the funds have been paid to the church, and then the situation before actual payment but after the alleged contract had been completed by offer and acceptance..$^{59}$

54 Cahill's III. Rev. Stats. I935, c. 32, $\$$ I73. The duty is of course owed to the members of the congregation as well as to the public generally. It follows that if there was no detriment to the church because this duty was owed, there was no benefit to the obligee because she was previously entitled to the promised performance. I Williston, Contracts $\$ 102$, 102a (2d ed. r936).

5s Attorney General v. Tllinois Agricultural College, 85 Ill. 516 (I877); Northwestern Univ. v. Wesley Memorial Hospital, 29o Ill. 205, I25 N.E. I3 (I9r9); State v. Toney, r4I Ore. 406, I7 P. (2d) Iro5 (I933); 2 Perry, Trusts and Trustees ${ }_{2} \S 733$ (7th ed. 1929).

${ }^{6}$ This is the reason given for denying tort liability. Parks v. Northwestern Univ., 2 I8 Ill. 381, 75 N.E. 99 I (1905).

57 See South Park Comm'rs v. Chicago City Ry. Co., 286 Ill. 504, 509, I22 N.E. 89,92 (r919); Rienzi Co. v. Comm'rs of Lincoln Park, I98 Ill. App. 218, 232 (I916); In re Smith Estate, 69 Vt. 382,38 Atl. 66 ( 1897 ). "In the absence of special circumstances, we fail to see how a duty to apply the fund to a particular corporate purpose can better serve as a consideration than a duty to apply it to corporate purposes not specified. The duty in either case is implied." Johnson v. Otterbein Univ., 4I Ohio St. 527, 53I (IS85); and see note 55 supre. But see Irwin v. Lombard Univ., 56 Ohio St. 9, 46 N.E. 63 (1897); and cases collected in 38 A.L.R. 878 (r925). Cf. Thompson v. Board of Supervisors, 40 Ill. 379 (I866).

$5^{8}$ Vogel v. Pekoc, ${ }_{57}$ Ill. $339,4^{2}$ N.E. 386 (r 895$)$. See I Williston, Contracts $\S$ ro3 (e) (2d ed. $x 936)$.

58 This reverse procedure is adopted because the court considered only the first point at any length and because from the conclusion that there are no enforceable rights after payment, a similar conclusion as to the situation prior in time is necessary. 
Examining the first situation, could the promisor have compelled performance of the obligation of the church to hold and administer the endowment fund as it had agreed to do? The court admitted the importance of this question and confidently answered the question in the affirmative..$^{60}$ Two cases are cited in support, neither of which is in point. ${ }^{6 x}$ In the Green case, the court enforced a provision in a gift for a reverting to the heirs of the donor if the property given was not used as specified. There was no such reverter provided for in the Wheeler case. In addition, this is clearly not enforcing the performance of the obligation to administer the fund. In the other case, ${ }^{62}$ in which there was also no reverter provided for, the same bench as sat in the Wheeler case refused to allow a contributor to a fund to enforce its proper administration or to get his money back. There is no indication that this case is overruled. It is devoted largely to distinguishing the principle invoked in the Green case. ${ }^{63}$

The only other case cited, the Allegheny College case, ${ }^{64}$ was one in which a college enforced a subscription, hardly a strong case for proving the rights of the subscriber against the college. Without spelling it out, the court there did indicate that a duty was owed to the promisor to perpetuate her name in connection with a promised scholarship fund. The resulting gratification of "the longing for posthumous remembrance" was the reason for holding that the promises were mutual consideration. This dictum, ${ }^{65}$ amounting to no more than an intimation as to the enforceability of the non-charitable feature of the agreement, is weak support indeed for the assertion in the. Wheeler case that the strictly charitable promises of the church could be enforced by a subscriber.

The question of whether rights were created in the subscriber on her "acceptance" and before payment must be answered in the negative for surely a prospective donor has no greater rights than one who has already

${ }^{60} 284$ Ill. App. 132, x42, I N.E. (2d) 425, 429 (r936).

6r Green v. Old People's Home, 269 Ill. 134, rog N.E. 7or (xg15); Allegheny College v. Nat'l Chautauqua County Bank, 246 N.Y. 369 , I59 N.E. 173 (I927).

62 Smith v. Thompson, 266 Ill. App. 165 (1932).

${ }^{63}$ In the Smith case the court said at p. 168: "... . we are of the opinion that a contributor to a fund creating a trust for public charitable purposes where, under no circumstances, is there any right of reverter and the contribution is made without reservation, has no right to call the trustees of the fund to account for a misapplication of the funds or any other breach of the trust."

${ }^{6}+246$ N.Y. 369, I 59 N.E. I73 (I927).

${ }^{65}$ Id. at 375 (N.E., at 775 ): "More is involved in the receipt of such a fund than in the mere acceptance of money to be held to a corporate use. ...." Again, at 337 (N.E. at I76): "A duty to act in ways beneficial to the promisor and beyond the application of the fund to the mere uses of the trust would be cast upon the promisee by acceptance of the money. 
contributed ${ }^{66}$ and it is clear, therefore, that she would not be able to institute suit if the church refused to receive the sums promised.

As long as charitable subscription cases are decided on promissory estoppel principles, the inroads upon consideration can at least be studied and to some extent predicted. Even an arbitrary rule that reliance by a charity is conclusively presumed would have the virtue of certainty and definitenéss and, it would seem, should give charities almost complete protection. Promissory estoppel is at least a direct attack on the necessity of consideration. When the court's determination to protect the expectations of charities leads them to begin chipping from within at the principles of consideration, however, confusion is promoted not only in cases involving promises to charities but in other cases involving the principles which have thus been distorted.

It is too early to predict that the Illinois law will follow this course. Any court not inclined to follow the Wheeler case has, as has been shown, ample opportunity to find authority as well as reason for its purpose.

${ }^{66}$ See note 62 supra. 